ISSN: 2224-0616

Int. J . Agril. Res. Innov. Tech. 8 (2): 13-23, December 2018

DOI: https://doi.org/ 10.3329/ijarit.v8i2.40551

Available online at https://ijarit.webs.com

https:// www.banglajol.info/index.php/ IJ ARIT

\title{
EFFECTS OF PERIPHYTON ON MONOCULTURE OF Puntius gonionotus
}

\section{M.I. Hoque', A.K.M.F. Rahman' ${ }^{2}$ M.A. Mansur ${ }^{3 *}$ and S. Rahman ${ }^{4}$}

Received 11 July 2018, Revised 16 November 2018, Accepted 26 December 2018, Published online 31 December 2018

\begin{abstract}
An experiment was carried out on the effects of periphyton on monoculture of Thai sharputi, Puntius gonionotus at the Department of Fisheries Management, Bangladesh Agricultural University, Mymensingh during 7th August to 8th November. In treatment-1 bamboo poles were used as artificial substrate for periphyton production and in treatment- 2 there was no artificial substrate (control). Each of the six ponds was stocked with 150 fingerlings of average size $6.41 \mathrm{~cm}$ and $3.60 \mathrm{~g}$. The ponds were fertilized fortnightly with manure (cow dung) at a rate of $10 \mathrm{~kg} \mathrm{decimal}^{-1}$, urea $60 \mathrm{~g} \mathrm{decimal}^{-1}$ and triple super phosphate $90 \mathrm{~g}$ decimal ${ }^{-1}$. During the experimental period, the ranges of physico-chemical parameters viz. air temperature $\left(31.0-35.5^{\circ} \mathrm{C}\right)$, water temperature $\left(29-32^{\circ} \mathrm{C}\right)$, water depth $(0.56-0.84 \mathrm{~m})$, transparency $(32-63 \mathrm{~cm})$, dissolved oxygen $\left(3.5-7.8 \mathrm{mg} \mathrm{L}^{-1}\right), \mathrm{pH}$ (6.8-7.9), total alkalinity (44-92 mg L-1), free $\mathrm{CO}_{2}\left(1.5-4.0 \mathrm{mg} \mathrm{L}^{-1}\right)$, phosphate-phosphorus $\left(0.31-1.07 \mathrm{mg} \mathrm{L}^{-1}\right)$ and nitrate-nitrogen (1.12-2.30 mg L-1) were within the productive range and more or less similar in the ponds under treatments- 1 and 2. Among the observed biological parameters, there were 35 genera of phytoplankton composed of five groups and 13 genera of zooplankton composed of four groups in the experimental ponds. Thirty three genera under the groups of Bacillariophyceae, Chlorophyceae, Cyanophyceae and Euglenophyceae formed the periphyton on bamboo poles in the experimental ponds. Net fish production of the ponds with periphyton under treatment- 1 was about 1.5 times higher than those of the ponds without periphyton (treatment-2). By analysis of variance, it was found that the net fish production of Thai sharputi under treatment-1 was significantly higher than that under treatment-2 $(p<0.05)$. Finally, it can be concluded that periphyton is one of the preferable food item of Thai sharputi and it is also suggested that growth and production of Thai sharputi can be increased if arrangement is made for periphyton production.
\end{abstract}

Keywords: Periphyton, Pond, Monoculture, Puntius gonionotus, Physical parameters of water, Chemical parameter of water, Biological parameters of water

\footnotetext{
${ }^{1}$ Department of Fisheries Management, Bangladesh Agricultural University, Mymensingh-2202, Bangladesh.

${ }^{2}$ Youth Training Centre, Netrokona- 2400, Bangladesh.

${ }^{3}$ Department of Fisheries Technology, Bangladesh Agricultural University, Mymensingh-2202, Bangladesh.

${ }^{4}$ Department of Fisheries Management, Bangladesh Agricultural University, Mymensingh-2202, Bangladesh.

*Corresponding author's email: mansurft63@gmail.com (M.A. Mansur)
}

Cite this article as: Hoque, M.I., Rahman, A.K.M.F., Mansur, M.A. and Rahman, S. (2018). Effects of periphyton on monoculture of Puntius gonionotus. Int. J. Agril. Res. Innov. Tech. 18(2), 13-23.

\section{Introduction}

In Bangladesh, most farmers in rural areas have ponds and ditches. Therefore, small scale fish culture can be done easily in these water bodies. While developing and transferring technologies, it is important to understand the farmer's resources, which should be better utilized for minimizing input costs and optimizing returns. Effects of periphyton on fish production as a new fish culture technology is expected to increase fish production with less investment and may attract the farmers for its simplicity.

In Bangladesh majority of farmers are unable to buy artificial fish feed. Because supplementary feed is more costly than natural food and in some cases feed ingredients are not easily available. Periphyton based fish culture can be an easy method for fish culture which might be easily practiced by the poor farmers in our country. In this experiment, locally available low-cost materials, bamboo poles were used as artificial substrate to grow periphyton as natural food for fishes.

Periphyton is that assemblage of organisms which commonly grow upon surfaces of submerged plants, forming a more or less continuous slimy coat (Welch, 1948). Periphyton comprises all 
attached organisms (except the macrophytes), including filamentous and other algae, diatom etc. (Ruttner, 1953).Organisms (both plant and animal) attached or clinging to stems and leaves of rooted plants or other surfaces projecting above the bottom are called periphyton (Odum, 1971). Periphyton, attached algae, are the most important primary producer in a water body (Wilham et al., 1978). Periphyton is one of preferable food materials for some fishes especially Thai sharputi (Puntius gonionotus). It is one of the most important herbivorous species commercially cultivated in freshwater ponds. To maximize its production in monoculture or ploy culture, the cultural technique of this species must be developed under the existing environmental conditions. On the basis of food materials, herbivorous and omnivorous fish species are the most suitable for periphytonbased fish culture as some of them take considerable amounts of periphyton which enhance their growth considerably. Some experiments have been conducted on the effects of periphyton on production of different fish species in Bangladesh (Rashid, 1999; Tasneem, 1998; Kawser, 1998; Nahar, 1997; Azam, 1996; Haque, 1996). Some other research works performed on various aspects of periphyton in districts of Bangladesh as well as in different countries of the world (Das et al., 1944; Khondker and Rahim, 1993; Wargasamita, 1991; SukaneBoonpirote, 1990; Neverauskas, 1988 ; Markosova, 1980; Eskinazi-Leea et al., 1980). However, the effects of periphytons, produced on artificial substratum, on the growth and production of planktivorous fish Puntius gonionotus were not studied.

Considering these facts the present study was undertaken with the objectives to estimate the periphyton that grows on bamboo poles qualitatively and quantitatively; to determine the water quality parameters of the ponds under the experiment; to estimate the plankton population of the experimental ponds both qualitatively and quantitatively; and to determine the effect of periphyton on monoculture of Thai sharputi (Puntius gonionotus).

\section{Materials and Method}

\section{Experimental ponds}

A series of six ponds from the experimental pond facilities of the Department of Fisheries Management, Bangladesh Agricultural University, Mymensingh were selected to perform the research work from $7^{\text {th }}$ August to $8^{\text {th }}$ November. The ponds were rectangular in shape having more or less similar size, depth, basin conformation, bottom soil type and contour. The ponds were free from aquatic vegetation and wellexposed to sunlight. The surface area of each of the pond was about 1 decimal $\left(40 \mathrm{~m}^{2}\right)$ with an average water depth of $0.65 \mathrm{~m}$. All the ponds were completely independent and having facility to supply water from a deep tube-well. The ponds were not interconnected and had no inlets or outlets. The embankment was well protected and covered with grass. All the experimental ponds were arbitrarily numbered as pond no. $1\left(\mathrm{P}_{1}\right)$, pond no. $2\left(\mathrm{P}_{2}\right), \ldots \ldots \ldots \ldots$ and pond no. $6\left(\mathrm{P}_{6}\right)$ for the convenience of research work.

\section{Experimental layout}

The experiment was performed in Completely Randomized Design (CRD) in which two treatments $\left(T_{1}\right.$ and $\left.T_{2}\right)$ were used. Among the six ponds the pond nos. 1,3 and 6 were under treatment-1 $\left(\mathrm{T}_{1}\right)$ in which bamboo poles were used as artificial substrate for periphyton growth and the pond nos. 2, 4 and 5 were under treatment-2 $\left(\mathrm{T}_{2}\right)$ which were treated as control (without periphyton). The experimental design has been given in the table below.

Table 1. The layout of the experiment.

\begin{tabular}{|llll|}
\hline Treatment & Pond no. & Replication & Description \\
\hline $\mathrm{T}_{1}$ (With periphyton) & $\mathrm{P}_{1}, \mathrm{P}_{3}, \mathrm{P}_{6}$ & 3 & Periphyton grown on bamboo poles \\
\hline $\mathrm{T}_{2}$ (Control) & $\mathrm{P}_{2}, \mathrm{P}_{4}, \mathrm{P}_{5}$ & 3 & No arrangement for periphyton growth \\
\hline
\end{tabular}

\section{Preparation of pond}

The ponds under this experiment were free from aquatic vegetation. All kinds of weed fishes were removed by rotenone treatment. The aquatic vegetation of the embankment were cleaned manually. Lime $(\mathrm{CaO})$ was applied in all the ponds at the rate of $2 \mathrm{~kg}$ decimal as initial dose seven days before fertilization. Seventy-five bamboo poles, each about 1.5 meter long as artificial substrate for periphyton growth, were inserted into the pond bottom vertically at 0.5 meter except in pond nos. 1, 3 and 6. Bamboo poles were penetrated into the bottom-mud of the ponds in such a way that they remain in straight standing position emerging upper portions through water surface.

\section{Fertilization of pond}

Fertilization of pond was done fortnightly with manure (cow dung) urea and triple super phosphate. Cow dung was applied as organic manure at a rate of $10 \mathrm{~kg} \mathrm{decimal}^{-1}$ and urea and triple super phosphate (TSP) were applied at the rate of $60 \mathrm{~g} \mathrm{decimal}^{-1}$ and $90 \mathrm{~g}^{\text {decimal- }}{ }^{-1}$, 
respectively. Cow dung was applied at every corner of each pond as bulky amount but TSP and urea were applied after mixing together and dissolving in a plastic bucket before 24 hours of application. Dissolved urea and TSP was applied by spreading on pond surface manually.

\section{Stocking of fish}

After 7 days of fertilization fingerlings of Thai sharputi (Puntius gonionotus) were stocked in all the ponds at the density of 150 fish per decimal. The initial average length and weight of fingerlings were $6.41 \mathrm{~cm}$ and $3.60 \mathrm{~g}$, respectively. All the fingerlings were collected from Bangladesh Fisheries Research Institute, Mymensingh. Transportation of fingerlings was done carefully to minimize the stress and mortality. Before releasing the fingerlings proper conditioning was done.

\section{Study of water quality parameters}

During the experiment, the water quality parameters were recorded fortnightly. Water depth $(\mathrm{m})$, transparency $(\mathrm{cm})$, water temperature $\left({ }^{\circ} \mathrm{C}\right)$, air temperature $\left({ }^{\circ} \mathrm{C}\right), \mathrm{pH}$, dissolved oxygen (mg L $\left.\mathrm{L}^{-1}\right)$, free carbon dioxide $\left(\mathrm{mg} \mathrm{L}^{-1}\right)$, total alkalinity $\left(\mathrm{mg} \mathrm{L}^{-1}\right), \mathrm{PO}_{4}-\mathrm{P}\left(\mathrm{mg} \mathrm{L}^{-1}\right), \mathrm{NO}_{3}-\mathrm{N}(\mathrm{mg} \mathrm{L}-$ 1), phytoplankton density (cells $\mathrm{L}^{-1}$ ), zooplankton density (cells $\mathrm{L}^{-1}$ ), periphyton grown on bamboo poles (cells $\mathrm{L}^{-1}$ ) were recorded and estimated fortnightly. Water samples were collected and transported in black glass bottles to the laboratory for chemical analysis. On the sampling day, sampling was started at about $8.30 \mathrm{a}$.m. and continued up to about 12.00 noon. The procedures and methods followed have been given below:

\section{Methods for study of physical parameters}

Water depth

Water depths of the ponds were measured with the help of a graduated wooden depth meter.

Transparency

Transparency of water of the pond was measured by Secchi-disc of $30 \mathrm{~cm}$ in diameter.

Temperature

Air temperature and water temperature were recorded by a mercury Celsius thermometer (1 div. $=0.1^{10} \mathrm{C}$.

\section{Methods for study of chemical parameters}

Dissolved oxygen (D.O.)

To determine dissolved oxygen, water samples were collected in $500 \mathrm{ml}$ black glass bottles and carried to the laboratory of the Department of Fisheries Management, Bangladesh Agricultural University, Mymensingh. Dissolved Oxygen was measured by Azide-modification of Iodometric method (APHA, 1971).

\section{$\mathrm{pH}$ (Hydrogen-ion concentration)}

For the determination of $\mathrm{pH}$ of water, samples were collected in $500 \mathrm{ml}$ black glass bottles and carried to the laboratory and then $\mathrm{pH}$ was determined by an electronic pH meter (J enway, MODEL 3020, UK).

Free carbon dioxide

To measure free carbon dioxide of water, samples were collected in $500 \mathrm{ml}$ black glass bottles and titrated with $0.0227 \mathrm{~N}$ sodium hydroxide solution using phenolphthalein as indicator (APHA, 1971).

\section{Total alkalinity}

To determine total alkalinity, samples were collected in $500 \mathrm{ml}$ black glass bottles and total alkalinity was determined by Methyl Orange Indicator Method (APHA, 1971).

Phosphate-phosphorus ( $\left.\mathrm{PO}_{3}-\mathrm{P}\right)$

To determine phosphate-phosphorus, water samples were collected and filtered through high quality glass-microfibre filter paper (Whatman GF/C Cat. No. 1822048) with the help of vacuum pressure air pump. Then phosphate-phosphorus $\left(\mathrm{PO}_{3}-\mathrm{P}\right)$ was determined by using a Hach Kit (DR2000) and reagent pillow phosver- 3 .

\section{Nitrate-nitrogen $\left(\mathrm{NO}_{3}-\mathrm{N}\right)$}

In order to determine nitrate-nitrogen $\left(\mathrm{NO}_{3}-\mathrm{NO}\right)$ water samples were collected and filtered through high quality glass-microfibre filter paper with the help of vacuum pressure air pump. Then nitratenitrogen $\left(\mathrm{NO}_{3}-\mathrm{N}\right)$ was determined by using a hach Kit (DR-2000) and reagent pillow Nitrover5.

\section{Methods for study of Biological parameters}

\section{Plankton}

\section{Collection and preservation of sample}

For the quantitative and qualitative study of phytoplankton and zooplankton of water, ten litres of water samples were randomly collected from different sites of the ponds and passed through a plankton net of 55 micron mesh size and finally concentrated to $20 \mathrm{ml}$. Then concentrated samples were preserved in small plastic bottles in $5 \%$ formalin for further study.

\section{Counting of plankton}

Both phytoplankton and zooplankton counting were done with the help of Sedgwick-Rafter counting cell (S-R cell). The cell is $50 \mathrm{~mm}$ long and $20 \mathrm{~mm}$ wide and $1 \mathrm{~mm}$ deep. The volume of the chamber is equally divided into 1000 fields of $0.001 \mathrm{ml}$ each. From the concentrated plankton 
samples, $1 \mathrm{ml}$ was taken by a dropper and then put in the S-R cell. The counting chamber was covered with a cover slip in order to eliminate the air bubbles and left to stand for about 10 minutes to allow the plankton settle down and then it was studied under a compound microscope and plankton were counted in 10 random fields.

Identification of plankton

Identification of plankton up to generic level of both phytoplankton and zooplankton were made according to Ward and Whipple (1959), Smith (1950), Pennak (1953), Needham and Needham (1962), Presscott (1962), Belcher and Swale (1978).

\section{Calculation}

The plankton population was determined by using the following formula (Rahman, 1992):

$$
\mathrm{N}=\frac{\mathrm{Ax} 1000 \times \mathrm{C}}{\mathrm{V} \times \mathrm{F} \times \mathrm{L}}
$$

Where, $\mathrm{N}=\mathrm{No}$. of plankton cells per litre of original water

A = Total no. of plankton counted

$\mathrm{C}=$ Volume of final concentration of sample in $\mathrm{ml}$ $\mathrm{V}=$ Volume of a field $=1 \mathrm{~mm}^{2}$

$\mathrm{F}=$ No. of fields counted

$\mathrm{L}=$ Volume of original water in litre; The number of phytoplankton and zooplankton were expressed as cells $\mathrm{L}^{-1}$

Periphyton

Collection and preservation of sample: Periphyton samples were collected from bamboo poles by scraping 1 square inch area by a razor blade. Scraping samples were kept in $20 \mathrm{ml}$ water and vigorous shaking was done. The samples were kept in vials and preserved in 5\% formalin for further study.

Study under a microscope

Periphyton densities were estimated by a Sedgewick-Rafter counting cell (S-R cell). The cell was filled and covered with a coverslip so as to eliminate air bubbles and left for 10 minutes to settle the periphyton. Then periphytons were counted in ten fields of S-R cell which were selected randomly under a binocular compound microscope (Swift, Model 4000-D).

Identification of periphyton

Identification of periphyton was done according to the methods stated before which are same as for plankton identification.
Calculation

Periphyton densities on bamboo poles was calculated by using the following formula (Rahman, 1998).

Periphyton density (cells $\mathrm{cm}^{-2}$ )

$$
\begin{aligned}
& \text { Ax } 1000 \times C \\
& \mathrm{~N}=\ldots \ldots \ldots \ldots \ldots \ldots \ldots \ldots \ldots \\
& \text { Vx FxAR }
\end{aligned}
$$

Where,

$\mathrm{A}=$ Total no. of periphyton counted

$\mathrm{C}=$ Volume of scraping in $\mathrm{ml}$.

$\mathrm{V}=$ Volume of a field $=1 \mathrm{~mm}^{3}$

$\mathrm{F}=$ No. of fields counted

$\mathrm{AR}=$ Area of scraping collection in $\mathrm{cm}^{2}$

\section{Statistical analysis}

Analysis of variance (ANOVA) of net fish production of the ponds under treatment- 1 and treatment-2 ( $T_{1}$ and $\left.T_{2}\right)$ was done by computer programme.

\section{Results and Discussion}

\section{Physical parameters}

The result of the physical parameters of water of the experimental ponds have been presented in the Tables 2 and 3 .

\section{Water depth (m)}

The water depth of the ponds under treatment- 1 varied from 0.57 to $0.80 \mathrm{~m}$ and those of the ponds under treatment- 2 varied from 0.56 to $0.84 \mathrm{~m}$ during the study period (Tables 2 and 3 ). The mean values of the water depth of the ponds 1,3 and 6 under treatment- 1 were $0.61 \pm 0.03$, $0.64 \pm 0.06$ and $0.69 \pm 0.06 \mathrm{~m}$, respectively (Table 2 ) and mean values of water depth of the pond nos. 2, 4 and 5 under treatment-2 were $0.66 \pm 0.04, \quad 0.73 \pm 0.06$ and $0.61 \pm 0.04 \mathrm{~m}$, respectively (Table 3 ). The highest water depth $0.84 \mathrm{~m}$ was recorded in August in pond no. 4 and the lowest water depth $0.56 \mathrm{~m}$ was recorded in October in the pond no. 5. During the experiment fortnightly fluctuations of water depth ranged from 0.56 to $0.84 \mathrm{~m}$. The productivity of a water body is greatly influenced by its depth. In shallow water bodies sun light penetrates up to the bottom and thus increases the productivity. Rahman et al. (1982) stated that pond should not be shallower than $1 \mathrm{~m}$ and deeper than $5 \mathrm{~m}$ and optimum depth should be $2 \mathrm{~m}$. J hingran (1975) stated that a depth of about $2 \mathrm{~m}$ of a pond is suitable from the viewpoint of biological productivity. The mean values of water depth under treatment-1 and treatment-2 were $0.65 \pm 0.05 \mathrm{~m}$ and $0.67 \pm 0.05 \mathrm{~m}$, respectively as the ponds were shallow and for high seepage water depths were below $1 \mathrm{~m}$, although regular water supply was done from a water supplysystem of a deep tube-well. 
Water transparency $(\mathrm{cm})$

During the experiment the water transparency values of the ponds under treatment- 1 varied from 30.0 to $62.0 \mathrm{~cm}$ and those of the ponds under treatment-2 varied from 34.0 to $63.0 \mathrm{~cm}$ (Tables 2 and 3 ). The mean values of water transparency of the ponds 1,3 , and 6 under treatment- 1 were $37.33 \pm 6.80,39.50 \pm 8.70$ and $44.33 \pm 9.60 \mathrm{~cm}$, respectively (Table 2 ) and those of ponds 2,4 and 5 under treatment-2 were $1.60 \pm 11.07, \quad 44.0 \pm 10.3$ and $43.3 \pm 9.5 \mathrm{~cm}$, respectively (Table 3 ). The minimum and maximum values of water transparency recorded were $30.0 \mathrm{~cm}$ in September in the pond no. 3 and $63.0 \mathrm{~cm}$ in August in the pond no. 2, respectively. Nahar (1997), Kawser (1998), Tasneem (1998), Rashid (1999) recorded almost similar transparency of pond water under similar experiments. Rahman (1992) stated that the transparency of productive water bodies should be $40 \mathrm{~cm}$ or less (turbidity resulting from plankton). The transparency of a water body normally indicates its productivity. In the present experiment the water transparency values of treatments-I and II were closely near productive range. Reid and Wood (1976) reported that the transparency of water was affected by several factors such as silting, microscopic organisms, suspended organic matter, latitude, season, the angle and intensity of light penetration. McCombie (1953) also found similar results.

Water temperature $\left({ }^{\circ} \mathrm{C}\right)$

The water temperature of the experimental ponds were found to vary from 29.0 to $32^{\circ} \mathrm{C}$ (Tables 2 and 3). The mean values of water temperature of the ponds 1,3 and 6 under treatment- 1 were $30.00 \pm 0.70, \quad 30.43 \pm 0.79$ and $30.45 \pm 0.98^{\circ} \mathrm{C}$, respectively and those of the ponds 2,4 and 5 under treatment- 2 were $30.00 \pm 0.70,30.36 \pm 0.85$ and $30.58 \pm 0.92^{\circ} \mathrm{C}$, respectively (Tables 2 and 3 ). The highest and the lowest water temperature were recorded in August and in October in the pond nos. 5, 6 and pond no. 1, respectively. Temperature has direct effect on the physical, chemical and biological conditions of a water body. In the present experiment, the water temperature fluctuated between 29.0 to $32^{\circ} \mathrm{C}$ which was within suitable range. Ganapati (1941), Durve and Bal (1961), Kawser (1998), Tasneem (1998), and Rashid (1999) found almost similar results. Ali et al. (1982) found water temperature of ponds 20.5 to $36.5^{\circ} \mathrm{C}$, which was favourable for fish culture. Rahman et al. (1982) found water temperature of ponds 26.06 to $31.970 \mathrm{C}$, which was within the suitable range for fish culture.

Air temperature $\left({ }^{\circ} \mathrm{C}\right)$

Air temperature was same for all experimental ponds on each sampling day. The air temperature ranged from 31.0 to $35.5^{\circ} \mathrm{C}$ during the experimental period (Tables 2 and 3). The highest air temperature recorded was $35.5^{\circ} \mathrm{C}$ in August and $31.0^{\circ} \mathrm{C}$ was the lowest air temperature recorded in September. The mean value of air temperature during the experimental period was $33.00 \pm 1.73^{\circ} \mathrm{C}$. Temperature has direct effect on the physical, chemical and biological conditions of a water body. In the present experiment, the water temperature fluctuated between 29.0 to $32.0^{\circ} \mathrm{C}$ and air temperature between 31.0 to $35.5^{\circ} \mathrm{C}$. In the present study, water temperature was within suitable range. Previous research studies conducted by other researchers e.g Ganapati (1941), Durve and Bal (1961), Kawser (1998), Tasneem (1998), and Rashid (1999) found almost similar results.

\section{Chemical parameters}

\section{Dissolved oxygen $\left(\mathrm{mg} \mathrm{L}^{-1}\right)$}

During the study period dissolved oxygen content of the experimental ponds under treatment-1 varied from 3.5 to $7.8 \mathrm{mg} \mathrm{L}^{-1}$ and those under treatment-2 varied from 3.7 to $7.0 \mathrm{mg} \mathrm{L}^{-1}$. The mean values of dissolved oxygen in the pond nos. 1,3 and 6 under treatment- 1 were $4.90 \pm 0.83$, $4.50 \pm 1.18$ and $5.09 \pm 1.43 \mathrm{mg} \mathrm{L}^{-1}$, respectively and those of the pond nos. 2, 4, and 5 under treatment- 2 were $4.80 \pm 0.91,4.70 \pm 1.03$ and $4.90 \pm 1.0 \mathrm{mg} \mathrm{L}^{-1}$, respectively. Dissolved oxygen content of a water body is very important for fish culture. During the experimental period, dissolved oxygen content recorded between 3.5 to $7.8 \mathrm{mg} \mathrm{L}^{-1}$. Haque (1996), found more or less similar results. According to Rahman (1992), dissolved oxygen content of a productive pond should be 5 ppm or more. Banerjea (1967) stated that 5-7 ppm of dissolved oxygen of a water body is good for productivity and waters having dissolved oxygen below $5.0 \mathrm{ppm}$ to be unproductive. Ellis (1937) reported that the dissolved oxygen content at levels of $3 \mathrm{ppm}$ or below should be regarded as hazardous to lethal and $5 \mathrm{ppm}$ or more is suitable for fish production. In the present study, the mean dissolved oxygen values were closely near to suitable range.

Free $\mathrm{CO}_{2}\left(\mathrm{mg} \mathrm{L}^{-1}\right)$

During the study period free carbon dioxide concentration of the ponds with periphyton (treatment-1) varied from a minimum of $2.0 \mathrm{mg}$ $\mathrm{L}^{-1}$ to a maximum of $4.0 \mathrm{mg} \mathrm{L}^{-1}$ and those of ponds under treatment- 2 (control) varied from a minimum of 1.5 to a maximum of $4.0 \mathrm{mg} \mathrm{L}^{-1}$ (Tables 2 and 3). The average values of free carbon dioxide of the pond nos. 1, 3, and 6 under treatment- 1 were $2.65 \pm 0.57,3.30 \pm 0.72$ and $3.20 \pm 0.69 \mathrm{mg} \mathrm{L}^{-1}$, respectively and those of the pond nos. 2, 4 and 5 under treatment- 2 were $3.25 \pm 0.68,2.83 \pm 0.81$ and $2.80 \pm 0.25 \mathrm{mg} \mathrm{L}^{-1}$, 
respectively (Tables 2 and 3 ). Fortnightly fluctuations of free carbon dioxide ranged from 2.0 to $4.0 \mathrm{mg} \mathrm{L}^{-1}$. Azam (1996), Haque (1996), Nahar (1997), Kawser (1998), Tasneem (1998) and Rashid (1999) observed more or less similar results and the range was fairly suitable for fish culture. According to Lagler (1972), free $\mathrm{CO}_{2}$ more than $20 \mathrm{mg} \mathrm{L}^{-1}$ may be harmful to fishes and even lower concentration may be equally harmful when dissolved oxygen contents are less than 3 $\mathrm{mg} \mathrm{L}^{-1}$. According to Ruttner (1953) at very lower values even at $0 \mathrm{mg} / \mathrm{L}$ of free $\mathrm{CO}_{2}$ the photosynthetic activities of phytoplankton occurs normally. In this case, free $\mathrm{CO}_{2}$ comes from degradation of bicarbonate. Free $\mathrm{CO}_{2}$ and dissolved $\mathrm{O}_{2}$ showed more or less inverse relationship. Dewan (1973) and Rahman et al. (1982) also observed similar relationship in their studies.

pH (Hydrogen-ion-concentration)

The $\mathrm{pH}$ values of experimental ponds were about neutral, which have been presented in Tables 2 and 3. The mean $\mathrm{pH}$ values of the pond nos. 1, 3, and 6 under treatment-1 were $7.47 \pm 0.31$, $7.34 \pm 0.20$ and $7.30 \pm 0.22$, respectively and those of the ponds 2, 4 and 5 under the treatment- 2 were $7.50 \pm 0.32,7.30 \pm 0.22$ and $7.20 \pm 0.33$, respectively (Tables 2 and 3). $\mathrm{pH}$ varied from a minimum of 6.9 to a maximum of 7.9 in the ponds with periphyton (Treatment-1) and those of the ponds without periphyton (Treatment-2) varied from a minimum of 6.8 to a maximum of 7.8 (Tables 2 and 3). During the experiment $\mathrm{pH}$ values of most of the ponds were slightly alkaline which indicate good $\mathrm{pH}$ conditions for fish culture. Banerjea (1967) observed that average fish production might be expected in the $\mathrm{pH}$ range of 7.5 to 8.5. According to Swingle (1867), $\mathrm{pH} 6.5$ to 9.0 is suitable for pond fish culture and $\mathrm{pH}$ more than 9.5 is unsuitable because free $\mathrm{CO}_{2}$ is not available in this situation. At pH 11 fishes die, $\mathrm{pH}$ less than 6.5 reduces fish growth, physiological activities and tolerance to toxic substances. According to Boyd (1982), the acidic and alkaline death points for fish are about $\mathrm{pH} 4$ and 11, respectively. Thus it may be concluded that all of the experimental ponds were under the study were suitable for fish culture on the basis of $\mathrm{pH}$.

Total alkalinity $\left(\mathrm{mg} \mathrm{L}^{-1}\right)$

During the experimental period total alkalinity of the ponds under treatment-1 (with periphyton) varied from a minimum of $44 \mathrm{mg} \mathrm{L}^{-1}$ to a maximum of $92.0 \mathrm{mg} \mathrm{L}^{-1}$ and those of the ponds under treatment-2 (control) varied from a minimum of $42 \mathrm{mg} \mathrm{L}^{-1}$ to a maximum of $100 \mathrm{mg}$ $\mathrm{L}^{-1}$ (Tables 2 and 3 ). The mean values of total alkalinity of the pond nos. 1, 3 and 6 under treatment- 1 were $51.0 \pm 5.6,67.5 \pm 8.5$ and
$60.0 \pm 16.30 \mathrm{mg} \mathrm{L}^{-1}$ and those of the pond nos. 2, 4 and 5 were $57.8 \pm 21.7,72.6 \pm 12.3$ and $62.6 \pm 16.8$ mg L ${ }^{-1}$, respectively (Tables 2 and 3). The mean values of total alkalinity of the ponds under treatment I and treatment-2 were 59.4 \pm 9.3 and $64.3 \pm 16.3 \mathrm{mg} \mathrm{L}^{-1}$, respectively. Azam (1996), Haque (1996), Nahar (1997), Kawser (1998) and Tasneem (1998) found nearly similar result. According to Rahman (1992), total alkalinity of productive ponds should be $20 \mathrm{ppm}$ or more and total alkalinity usually may range from zero to several hundred ppm. From the result of total alkalinity of the present study, it can be concluded that all the ponds of this experiment were suitable for fish culture with regard to total alkalinity.

\section{Phosphate-phosphorus (mg L-1)}

Phosphate-phosphorus of the ponds with periphyton (treatment-1) varied from a minimum of $0.31 \mathrm{mg} \mathrm{L}^{-1}$ to a maximum of $1.07 \mathrm{mg} \mathrm{L}^{-1}$ (Tables 4 and 5) and those of the ponds under treatment-2 varied from a minimum of $0.41 \mathrm{mg} \mathrm{L}$ 1 to a maximum of $0.83 \mathrm{mg} \mathrm{L}^{-1}$ (Tables 2 and 3). The mean values of phosphate-phosphorus of the pond nos. 1,3 and 6 under treatment- 1 were $0.52 \pm 0.15,0.66 \pm 0.23$ and $0.61 \pm 0.19 \mathrm{mg} \mathrm{L}^{-1}$, respectively and those of the pond nos. 2,4 and 5 under treatment- 2 were $0.67 \pm 0.08,0.55 \pm 0.12$ and $0.66 \pm 0.09 \mathrm{mg} \mathrm{L}^{-1}$, respectively (Tables 2 and 3 ). The mean values of PO4-P of the experimental ponds under treatment- 1 and treatment- 2 were $0.59 \pm 0.16$ and $0.62 \pm 0.07 \mathrm{mg} \mathrm{L}^{-1}$, respectively. Haque (1996), Nahar (1997), Kawser (1998), Tasneem (1998), Rashid (1999) found more or less similar results. According to Alikunhi (1957), phosphate-phosphorus ranged from 0.20 to 0.40 $\mathrm{mg} \mathrm{L}^{-1}$ are within good productive range. Islam and Saha (1975) noticed that phosphatephosphorus from 0.20 to $2.80 \mathrm{mg} \mathrm{L}^{-1}$ are favourable for growth of blue green algae and diatoms. In the present study, phosphatephosphorus content was slightly higher as phosphate fertilizer was applied regularly.

\section{Nitrate nitrogen ( $\left.\mathrm{mg} \mathrm{L}^{-1}\right)$}

Nitrate nitrogen of the ponds with periphyton (treatment-1) varied from a minimum of $1.41 \mathrm{mg}$ $\mathrm{L}^{-1}$ to a maximum of $2.31 \mathrm{mg} \mathrm{L}^{-1}$ (Tables 2 and 3) and those of the ponds under treatment- 2 varied from a minimum of $1.12 \mathrm{mg} \mathrm{L}^{-1}$ to a maximum of $2.03 \mathrm{mg} \mathrm{L}^{-1}$ (Tables 2 and 3). The mean values of nitrate nitrogen of the pond nos. 1,3 and 6 under treatment- 1 were $1.92 \pm 0.17,1.81 \pm 0.27$ and $1.64 \pm$ $0.15 \mathrm{mg} \mathrm{L}^{-1}$, respectively and those of the pond nos. 2,4 and 5 under treatment- 2 were $168 \pm$ $0.34,1.66 \pm 0.22$ and $1.49 \pm 0.27 \mathrm{mg} \mathrm{L}^{-1}$, respectively (Tables 2 and 3). The mean values of nitrate-nitrogen of the ponds under treatments I and II were $1.81 \pm 0.11$ and $1.61 \pm 0.11 \mathrm{mg} \mathrm{L}^{-1}$, respectively. According to Bhuyan (1970), nitrate- 
nitrogen ranged from 0.06 to $0.10 \mathrm{ppm}$ are of present experiment nitrate-nitrogen were slightly productive range. Alikunhi (1957) reported that higher than those mentioned earlier. Chemical good pond water for fish culture should have a fertilization probably enhanced the amount of concentration of $0.06 \mathrm{ppm}$ of nitrate. In the nitrate-nitrogen.

Table 2. Physico-chemical and biological parameters of the ponds with periphyton (Treatment-1).

\begin{tabular}{|c|c|c|c|c|}
\hline \multirow[t]{2}{*}{ Parameters } & \multicolumn{3}{|c|}{ Mean \pm S.D. } & \multirow[t]{2}{*}{ Mean \pm S.D. } \\
\hline & $\mathrm{P}_{1}$ & $\mathrm{P}_{2}$ & $\mathrm{P}_{3}$ & \\
\hline Water depth (m) & $0.61 \pm 0.03$ & $0.64 \pm 0.60$ & $0.69 \pm 0.60$ & $0.64 \pm 0.04$ \\
\hline Transparency (cm) & $37.33 \pm 6.80$ & $39.50 \pm 8.70$ & $44.33 \pm 9.60$ & $40.38 \pm 3.58$ \\
\hline Water temperature $\left({ }^{\circ} \mathrm{C}\right)$ & $30.00 \pm 0.70$ & $30.43 \pm 0.79$ & $30.45 \pm 0.98$ & $30.29 \pm 0.25$ \\
\hline Air temperature $\left({ }^{\circ} \mathrm{C}\right)$ & $33.00 \pm 1.73$ & $33.00 \pm 1.73$ & $33.00 \pm 1.73$ & $33.00 \pm 1.73$ \\
\hline $\mathrm{pH}$ & $7.47 \pm 0.31$ & $7.34 \pm 0.20$ & $7.30 \pm 0.22$ & $7.37 \pm 0.09$ \\
\hline Dissolved $\mathrm{O}_{2}\left(\mathrm{mg} \mathrm{L}^{-1}\right)$ & $4.90 \pm 0.83$ & $4.50 \pm 1.18$ & $5.09 \pm 1.43$ & $4.83 \pm 0.30$ \\
\hline Free $\mathrm{CO}_{2}\left(\mathrm{mg} \mathrm{L}^{-1}\right)$ & $2.65 \pm 0.57$ & $3.30 \pm 0.72$ & $3.20 \pm 0.69$ & $3.05 \pm 0.35$ \\
\hline Total alkalinity (mg L-1) & $51.00 \pm 5.60$ & $67.50 \pm 8.50$ & $60.00 \pm 16.03$ & $59.50 \pm 8.26$ \\
\hline $\mathrm{PO}_{4}-\mathrm{P}\left(\mathrm{mg} \mathrm{L}^{-1}\right)$ & $0.52 \pm 0.15$ & $0.66 \pm 0.23$ & $0.61 \pm 0.19$ & $0.59 \pm 0.07$ \\
\hline $\mathrm{NO}_{3}-\mathrm{N}\left(\mathrm{mg} \mathrm{L}^{-1}\right)$ & $1.92 \pm 0.17$ & $1.81 \pm 0.27$ & $1.64 \pm 0.15$ & $1.79 \pm 0.14$ \\
\hline Phytoplankton (x103, cells L-1) & $55.70 \pm 10.70$ & $47.79 \pm 7.00$ & $53.70 \pm 14.52$ & $52.39 \pm 4.11$ \\
\hline Zooplankton (x103, cells L-1) & $9.05 \pm 0.92$ & $7.93 \pm 0.90$ & $7.86 \pm 0.53$ & $8.28 \pm 0.66$ \\
\hline $\begin{array}{l}\text { Periphyton grown on bamboo } \\
\left.\text { Poles (x103, cells } \mathrm{L}^{-1}\right)\end{array}$ & $78.03 \pm 8.21$ & $81.74 \pm 6.96$ & $92.16 \pm 9.19$ & $83.97 \pm 7.32$ \\
\hline Net production $\left(\mathrm{kg} \mathrm{ha}^{-1} \mathrm{yr}^{-1}\right)$ & 883.27 & 631.33 & 823.99 & $779.53 \pm 131.75$ \\
\hline Net production (ton ha-1 $\mathrm{yr}^{-1}$ ) & 0.883 & 0.631 & 0.823 & $0.779 \pm 0.131$ \\
\hline Gross production $\left(\mathrm{kg} \mathrm{ha}^{-1} \mathrm{yr}^{-1}\right)$ & 1416.79 & 1164.85 & 1357.51 & $1313.05 \pm 131.72$ \\
\hline Gross production (ton ha-1 $\mathrm{yr}^{-1}$ ) & 1.417 & 1.165 & 1.358 & $1.31 \pm 0.131$ \\
\hline
\end{tabular}

Table 3. Physico-chemical and biological parameters of the ponds without periphyton (Treatment-2).

\begin{tabular}{|c|c|c|c|c|}
\hline \multirow{2}{*}{ Parameters } & \multicolumn{3}{|c|}{ Mean \pm S.D. } & \multirow{2}{*}{ Mean \pm S.D. } \\
\hline & $\mathrm{P}_{1}$ & $\mathrm{P}_{2}$ & $\mathrm{P}_{3}$ & \\
\hline Water depth (m) & $0.66 \pm 0.04$ & $0.73 \pm 0.06$ & $0.61 \pm 0.04$ & $0.66 \pm 0.06$ \\
\hline Transparency $(\mathrm{cm})$ & $41.60 \pm 11.07$ & $44.00 \pm 10.30$ & $43.30 \pm 9.50$ & $42.96 \pm 1.23$ \\
\hline Water temperature $\left({ }^{\circ} \mathrm{C}\right)$ & $30.00 \pm 0.70$ & $30.36 \pm 0.85$ & $30.58 \pm 0.92$ & $30.31 \pm 0.29$ \\
\hline Air temperature $\left({ }^{\circ} \mathrm{C}\right)$ & $33.00 \pm 1.73$ & $33.00 \pm 1.73$ & $33.00 \pm 1.73$ & $33.00 \pm 1.73$ \\
\hline $\mathrm{pH}$ & $7.50 \pm 0.32$ & $7.30 \pm 0.22$ & $7.20 \pm 0.33$ & $7.33 \pm 0.15$ \\
\hline Dissolved $\mathrm{O}_{2}\left(\mathrm{mg} \mathrm{L}^{-1}\right)$ & $4.80 \pm 0.91$ & $4.70 \pm 1.03$ & $4.90 \pm 1.00$ & $4.80 \pm 0.10$ \\
\hline Free $\mathrm{CO}_{2}\left(\mathrm{mg} \mathrm{L}^{-1}\right)$ & $3.25 \pm 0.68$ & $2.83 \pm 0.81$ & $2.80 \pm 0.25$ & $2.96 \pm 0.25$ \\
\hline Total alkalinity (mg L-1) & $57.80+21.70$ & $72.60 \pm 12.30$ & $62.60 \pm 16.80$ & $64.33 \pm 7.25$ \\
\hline $\mathrm{PO}_{4}-\mathrm{P}\left(\mathrm{mg} \mathrm{L}^{-1}\right)$ & $0.67 \pm 0.08$ & $0.55 \pm 0.12$ & $0.66 \pm 0.09$ & $0.62 \pm 0.06$ \\
\hline $\mathrm{NO}_{3}-\mathrm{N}\left(\mathrm{mg} \mathrm{L}^{-1}\right)$ & $1.68 \pm 0.34$ & $1.66 \pm 0.22$ & $1.49 \pm 0.27$ & $1.61 \pm 0.10$ \\
\hline Phytoplankton (x103, cells L-1) & $46.87 \pm 12.47$ & $47.18 \pm 8.38$ & $48.50 \pm 6.24$ & $47.51 \pm 0.86$ \\
\hline Zooplankton $\left(\mathrm{x}^{103}\right.$, cells $\left.\mathrm{L}^{-1}\right)$ & $8.20 \pm 0.63$ & $7.55 \pm 0.56$ & $7.25 \pm 0.45$ & $7.66 \pm 0.48$ \\
\hline Net production $\left(\mathrm{kg} \mathrm{ha}^{-1} \mathrm{yr}^{-1}\right)$ & 592.80 & 518.70 & 533.52 & $548.34 \pm 39.21$ \\
\hline Net production (ton ha-1 $\mathrm{yr}^{-1}$ ) & 0.592 & 0.518 & 0.533 & $0.547 \pm 0.03$ \\
\hline Gross production $\left(\mathrm{kg} \mathrm{ha}^{-1} \mathrm{yr}^{1}\right)$ & 1126.32 & 1052.22 & 1067.04 & $1081.86 \pm 39.21$ \\
\hline Gross production (ton ha-1 $\mathrm{yr}^{-1}$ ) & 1.126 & 1.052 & 1.067 & $1.08 \pm 0.03$ \\
\hline
\end{tabular}

\section{Biological parameters}

Phytoplankton

During the study period, 35 genera of phytoplankton belonging to 5 different groups of Bacillariophyceae, Cyanophyceae, Chlorophyceae, Euglenophyceae and Dinophyceae were found in the ponds. These are presented in Table 4. Fortnightly fluctuation of phytoplankton density of the experimental ponds with periphyton (Treatment-1) and without periphyton (Treatment-2) have been presented in Table 5. The mean values of phytoplankton density of the

pond no. 1,3 and 6 under treatment- 1 were $55.70 \pm 10.70,47.79 \pm 7.00$ and $53.70 \pm 14.52\left(x \quad 10^{3}\right)$ cells $\mathrm{L}^{-1}$, respectively and those of pond no. 2,4 and 5 under treatment- 2 were $46.87 \pm 12.47$, $47.18 \pm 8.38$ and $48.50 \pm 6.24\left(\mathrm{x} 10^{3}\right)$ cells $\mathrm{L}^{-1}$, respectively (Table 6). The average density of phytoplankton of the ponds under treatment-1 was $52.41 \pm 7.96\left(\mathrm{x} \mathrm{10}^{3}\right)$ cells $\mathrm{L}^{-1}$ and that of the ponds under treatment-2 was 47.51 \pm 8.16 (x 103) cells L ${ }^{-1}$. Haque (1996), Nahar (1997), Kawser (1998), Tasneem (1998), and Rashid (1999) found more or less similar results. A wide variety of phytoplankton were identified in terms of 
number and genera. There were thirty five genera of phytoplankton belonging to five different groups of Bacillariophyceae, Cyanophyceae, Chlorophyceae, Euglenophyceae and Dinophyceae found in the experimental ponds. Plankton population in number and genera were more or less similar to those found in the earlier studies conducted by several workers in the fish ponds under the present experiment.

\section{Zooplankton}

A total of 13 genera of zooplankton belonging to 4 groups of Cladocera, Copepoda, Rotifera and nauplius were found in the experimental ponds during the experimental period (Table 4). The mean values of the zooplankton density of the pond no. 1, 3 and 6 under treatment- 1 were $9.05 \pm 0.92,7.93 \pm 0.90$ and $7.86 \pm 0.53\left(\mathrm{x} \mathrm{10} 0^{3}\right)$ cells $\mathrm{L}^{-1}$, respectively and those of the pond no. 2,4 and 5 under treatment- 2 were $8.20 \pm 0.63$, $7.55 \pm 0.56$ and $7.25 \pm 0.45$ (x 103) cells $\mathrm{L}^{-1}$, respectively (Table 6). The average number of zooplankton of the ponds under treatment- 1 was $8.25 \pm 0.62\left(\mathrm{x} \mathrm{10} 0^{3}\right)$ cells $\mathrm{L}^{-1}$ and those of the ponds under treatment- 2 was $7.63 \pm 0.48$ ( $\mathrm{x} \mathrm{10}^{3}$ ) cells $\mathrm{L}^{-1}$. Zooplankton is one of the most important food items for fish. In the present experimental period the mean values of zooplankton in the ponds with periphyton were $9.05 \pm 0.92, \quad 7.93 \pm 0.90$ and $7.86 \pm 0.53\left({\mathrm{x} 10^{3}}^{3}\right.$ cells $\left.\mathrm{L}^{-1}\right)$ and those of the ponds without periphyton were $8.20 \pm 0.63,7.55 \pm 0.56$ and $7.25 \pm 0.45$ (x 103 cells $\mathrm{L}^{-1}$ ). Thirteen genera of zooplankton composed of Cladocera, Copepoda, Rotifera and nauplius were found in the ponds under the present study. Azam (1996), Haque (1996), Nahar (1997), Tasneem (1998) and Rashid (1999) found more or less similar results.

\section{Periphyton}

Some 33 genera of periphyton found on surface of bamboo poles, belong to 4 groups of Bacillariophyceae, Chlorophyceae, Cyanophyceae and Euglenophyceae in the ponds under treatment-1 (Table 5). The mean values of periphyton density of the pond no. 1, 3 and 6 under treatment- 1 were $78.03 \pm 8.21,81.74 \pm 6.96$ and 92.16 \pm 9.19 ( $\mathrm{x} \mathrm{103)}$ cells $\mathrm{cm}^{-2}$, respectively. Azam (1996), Haque (1996), Nahar (1997), Kawser (1998), Tasneem (1998) and Rashid (1999) found more or less similar results. Eloranta (1982) noticed that periphyton included both plankton and true plankton. In the present experiment various phytoplankton were found in the periphytic community grown on bamboo poles.

Table 4. Generic status of phytoplankton and zooplankton found in the experimental ponds.

\begin{tabular}{|lll|}
\hline Chlorophyceae & Phytoplankton & Zooplankton \\
Actinastrum & Bacillariophyceae & Crustacea \\
Ankistrodesmus & Actinella & Cladocera \\
Chlorella & Asterionella & Daphnia \\
Closterium & Cyclotella & Diaphanosoma \\
Gloeocystis & Diatoma & Copepoda \\
Gonatozygon & Fragilaria & Cyclops \\
Micrasterium & Navicula & Diaptomus \\
Oocystis & Surirella & Nauplius \\
Pediastrum & Synedra & Rotifera \\
Sphaerocystis & Tabellaria & Asplanchna \\
Scenedesmus & Cyanophyceae & Brachionus \\
Spirogyra & Anabaena & Filinia \\
Ulothrix & Aphanocapsa & Hexarthra \\
Volvox & Chroococcus & Keratella \\
Zygnema & Gleocapsa & Lecane \\
Euglenophyceae & Gomphospaeria & Polyarthra \\
Euglena & Mierismopedia & Trichocerca \\
Phacus & Microcystis & \\
& Oscillatoria & \\
Dinophyceae & & \\
Ceratium & & \\
\hline
\end{tabular}


Table 5. Generic status of periphyton found in the experimental ponds (grown on bamboo poles) under treatment- 1 .

\begin{tabular}{|lll|}
\hline Bacillariophyceae & Chlorophyceae & Cyanophyceae \\
\hline Actinella & Actinastrum & Anabaena \\
Cyclotella & AnkistrodesmusChlorella & Aphanocapsa \\
Cymbella & Chaetophora & Chroococcus \\
Fragilaria & Cladophora & Gloetrichia \\
Navicula & Closterium & Gomphospaeria \\
Nitzschia & Gonatozygon & Lyngbya \\
Surirella & Merismopedia & Oscillatoria \\
& Microspora & Rivularia \\
Euglenophyceae & Oedogonimum & Gleocapsa \\
Euglena & Pediastrum & \\
Phacus & Scenedesmus & \\
& Spirogyra & \\
& Ulothrix & \\
\hline
\end{tabular}

\section{Production of Fish}

The net and gross production of fish of the ponds under treatment- 1 and treatment-2 have been presented in the Table 6.

Under treatment- 1 in pond no. 1, 3 and 6 mean initial weight and mean final weight of fish were $0.54 \pm 0.0 \mathrm{~kg} \mathrm{decimal}^{-1}$ and $1.33 \pm 0.13 \mathrm{~kg} \mathrm{decimal}^{-1}$ 3 months $^{-1}$ (Table 6). Mean initial weight and mean final weight of fish of the pond no. 2, 4 and 5 under treatment- 2 were $0.54 \pm 0.0 \mathrm{~kg}^{-1 e c i m a l}{ }^{-1}$ and $1.095 \pm 0.03 \mathrm{~kg} \mathrm{decimal}^{-1} 3$ months $^{-1}$ (Table 6). The calculated net and gross productions of fish of pond no. 1, 3 and 6 under treatment- 1 were $0.833,0.631,0.823$ ton $\mathrm{ha}^{-1} \mathrm{yr}^{-1}$ and 1.417, 1.165, 1.358 ton ha $^{-1} \mathrm{yr}^{-1}$, respectively (Table 6). The calculated average net and gross productions of fish of treatment-1 and treatment-2 were $0.779 \pm 0.130,1.313 \pm 0.130$ ton ha $\mathrm{yr}^{-1}$ and $0.547 \pm 0.030, \quad 1.081 \pm 0.030$ ton ha-1 $\mathrm{yr}^{-1}$, respectively (Table 6). The net and gross production of fish of treatment- 1 were 1.42 and 1.21 times higher than those of the treatment-2, respectively. Percent increase of net and gross production of fish of treatment- 1 over treatment2 were $142.16 \%$ and $121.37 \%$, respectively (Table 7). Eskinazi-Leea et al. (1980), Haque (1996), Azam (1996), Nahar (1997), Kawser (1998), Tasneem (1998) and Rashid (1999) found more or less similar results. Eskanazi-Leea et al. (1980) observed that net fish production of the ponds with periphyton were about 1.56 times higher; Haque (1996) found 2.5 times higher; Azam (1996) found 3 times higher; Haque (1996) found 2 times higher; Nahar (1997) found 1.7 times (in pond with bamboo poles) and 1.44 times (in ponds with tree branches) higher; and Kawser (1998) found 1.61 times higher than those of the ponds without periphyton. Most of the physicchemical parameters of the ponds under treatment- 1 and treatment- 2 were more or less similar but production of fish of the ponds with periphyton were higher than those of the ponds without periphyton. Thus, periphyton had positive effects on production of fish.

During the experimental period physical, chemical and biological parameters such as water depth, transparency, air temperature, water temperature, $\mathrm{pH}$, dissolved oxygen, free carbon dioxide, total alkalinity, nitrate-nitrogen, phosphate-phosphorus, phytoplankton, zooplankton and periphyton were investigated fortnightly. All the water quality parameters were within the suitable range for fish culture. A total of thirty five genera of phytoplankton belonging to five different groups, thirteen genera of zooplankton belonging to four groups and 33 genera of periphyton belonging to four groups were found during the experimental period. The calculated gross and net fish production of the ponds under treatment- 1 were 1313.05 and 779.53 $\mathrm{kg} \mathrm{ha}^{-1} \mathrm{yr}^{-1}$ and that of the ponds under treatment2 were 1081.86 and $548.34 \mathrm{~kg} \mathrm{ha}^{-1} \mathrm{yr}^{1}$, respectively. Percent increase of net and gross fish productions of treatment- 1 over treatment- 2 were $142.16 \%$ and $121.37 \%$, respectively (Table 7 ). By analysis of variance of net productions of Puntius gonionotus under two treatments, it was found that F-value was significant at 5\% level (Table 8), so periphyton had significant effect on production of Puntius gonionotus. Result of the present research study indicates that arrangement of periphyton growth on bamboo poles to increase fish production will be economically profitable. By adopting this method production cost can be minimized considerably. Thus, fish culture based on periphyton can be a sustainable technology for fish farmers of Bangladesh. Finally, it may be concluded that periphytron is one of the most preferable food items for Puntius gonionotus. 
Table 6. Net and gross production of Puntius gonionotus of the ponds with periphyton (Treatment-1) and without periphyton (Treatment-2) during the experimental period.

\begin{tabular}{|c|c|c|c|c|c|c|c|c|c|}
\hline \multirow{2}{*}{$\begin{array}{l}\text { Treat } \\
\text { ment }\end{array}$} & \multirow[t]{2}{*}{ Pond No. } & Initial & Final total & \multicolumn{3}{|c|}{ Net production } & \multicolumn{3}{|c|}{ Gross production } \\
\hline & & $\begin{array}{l}\text { total wt. } \\
\text { (kg dec } \\
\text { 1.) }\end{array}$ & $\begin{array}{l}\text { wt. (kg dec- } \\
3 \text { months }^{-1} \text { ) }\end{array}$ & $\begin{array}{l}\text { Kg dec }^{-1} \\
\text { month }^{-1}\end{array}$ & $\mathrm{Kgha}^{-1} \mathrm{yr}^{-1}$ & Ton ha-1 $_{1}^{-1} \mathrm{yr}^{-}$ & $\begin{array}{l}\text { Kg dec }^{-1} \\
\text { month }^{-1}\end{array}$ & $\mathrm{Kg} \mathrm{ha}^{-1} \mathrm{yr}^{-1}$ & Ton ha-1 $\mathrm{yr}^{-1}$ \\
\hline \multirow{4}{*}{ T-I } & $\mathrm{P}_{1}$ & 0.54 & 1.435 & 0.298 & 883.27 & 0.833 & 0.478 & 1416.79 & 1.417 \\
\hline & $\mathrm{P}_{3}$ & 0.54 & 1.180 & 0.213 & 631.33 & 0.631 & 0.393 & 1164.85 & 1.165 \\
\hline & $\mathrm{P}_{6}$ & 0.54 & 1.375 & 0.278 & 823.99 & 0.823 & 0.458 & 1357.51 & 1.358 \\
\hline & Mean \pm SD & $0.54 \pm 0$ & $1.33 \pm 0.13$ & $0.26 \pm 0.04$ & $779.53 \pm 131$ & $0.779 \pm 0.13$ & $0.44 \pm 0.04$ & $1313.05 \pm 131$ & $1.31 \pm 0.13$ \\
\hline \multirow{4}{*}{ T-II } & $\mathrm{P}_{2}$ & 0.54 & 1.140 & 0.20 & 592.80 & 0.592 & 0.380 & 1126.32 & 1.126 \\
\hline & $\mathrm{P}_{4}$ & 0.54 & 1.065 & 0.175 & 518.7 & 0.518 & 0.355 & 1052.22 & 1.052 \\
\hline & $\mathrm{P}_{6}$ & 0.54 & 1.080 & 0.180 & 533.52 & 0.533 & 0.360 & 1067.04 & 1.067 \\
\hline & Mean \pm SD & $0.54 \pm 0$ & $1.09 \pm 0.03$ & $0.18 \pm 0.01$ & $\begin{array}{c}548.34 \pm 39 . \\
21\end{array}$ & $0.54 \pm 0.03$ & $0.36 \pm 0.01$ & $\begin{array}{c}1081.86 \pm 39 . \\
21\end{array}$ & $1.08 \pm 0.03$ \\
\hline
\end{tabular}

Table 7. Comparison of estimated net and gross yields of Puntius gonionotus of the experimental ponds under treatments-I and II (T-1 and T-2).

\begin{tabular}{|c|c|c|c|c|c|c|c|c|}
\hline Treatment & $\begin{array}{l}\text { Net Yield } \\
\mathrm{Kg} \mathrm{ha}^{-1} \mathrm{yr}^{-1}\end{array}$ & $\begin{array}{c}\text { Percent } \\
\text { increase of } \\
\text { T-I over } \\
\text { T-II }\end{array}$ & 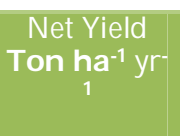 & $\begin{array}{c}\text { Percent } \\
\text { increase of } \\
\text { T-I over } \\
\text { T-II }\end{array}$ & $\begin{array}{l}\text { Gross Yield } \\
\mathrm{Kg} \mathrm{ha}^{-1} \mathrm{yr}^{-1}\end{array}$ & $\begin{array}{c}\text { Percent } \\
\text { increase of } \\
\text { T-I over } \\
\text { T-II }\end{array}$ & $\begin{array}{l}\text { Gross Yield } \\
\text { Ton ha-1 } \mathrm{yr}^{-1}\end{array}$ & $\begin{array}{c}\text { Percent } \\
\text { increase of } \\
\text { T-I over } \\
\text { T-II }\end{array}$ \\
\hline T-I & & $142.16 \%$ & 0.779 & $142.41 \%$ & & $121.37 \%$ & 1.313 & $121.46 \%$ \\
\hline T-II & 548.34 & $100 \%$ & 0.547 & $100 \%$ & 1081.86 & $100 \%$ & 1.081 & $100 \%$ \\
\hline
\end{tabular}

Table 8. ANOVA of net production of Puntius gonionotus of the ponds under treatments- 1 and 2 .

\begin{tabular}{|lcccc|}
\hline Source & DF & SS & MS & F-Value \\
\hline Between treatments & 1 & 80173.226 & 80173.226 & 8.489* \\
\hline Within treatments & 4 & 37776.769 & 9444.192 & \\
\hline Total & 5 & 117949.994 & & \\
\hline
\end{tabular}

$* \mathrm{p}<5 \%$

\section{Acknowledgement}

This research was conducted as part of M.S. thesis of Mr. Md. Israfil Hoque under the Supervision of Professor Md. Shahidur Rahman in the Department of Fisheries Management, Faculty of Fisheries, Bangladesh Agricultural University, Mymensingh-2202, Bangladesh.

\section{References}

Ali, S., Patwary, A.R. and Islam, K.R. 1982. Studies on the diurnal variations in physicochemical factors and zooplankton in a freshwater pond. Bangladesh J. Fish. 2-5 (12): 15-23.

Alikunhi, K.H. 1957. Fish culture in India. F.M. Bull. Indian Council Agric. Res. 20: 144.

APHA. 1971. Standard methods for the examination of wáter and waste wáter. American Public Health Association. 1015 Eighteenth Street, N. W. Washington, D.C. $874 \mathrm{p}$.

Azam, M.R. 1996. Effects of periphyton on Tilapia production. M.S. Thesis. Department of Fisheries Biology and Limnology, Faculty of Fisheries, Bangladesh Agricultural University, Mymensingh, Bangladesh. 97 p.

Banerjea, S.M. 1967. Water quality and soil condition of fish ponds in some states of India in relation to fish production. Indian J. Fish. 14: 115-144.
Belcher, H. and Swale, E. 1978. A Beginner's Guide to Freshwater Algae .Institute of Terrestrial Ecology, Natural Environment Research Council, London. $47 \mathrm{p}$.

Bhuyan, B.R. 1970. Physico-chemical qualities of some ancient tanks of Sibsagar, Assam. Environ. Health. 12: 129-134.

Boyd, C.E. 1982. Water quality management for pond fish culture. Elsevier Science Publishers B. V. 1000 AH Amsterdam, The Netherlands. $318 \mathrm{p}$.

Das, D.N., Mitra, K., Mukhopaddhya, P.K. and Choudhuri, D.K. 1944. Periphyton of the deep water rice field at Pearpur village, Hoogly, West Bengal, India. Environ. Ecol. 12 (3): 551-556.

Dewan, S. 1973. Investigation into the ecology of fishes of Mymensingh Lake. Ph.D. Thesis, Department of Aquaculture and Management, Faculty of Fisheries, Bangladesh Agricultural University, Mymensingh, Bangladesh. 335p.

Durve, V.S. and Bal, D.V. 1961. Hydrobiology of the Kelwabackwáter and adjoining sea. J. Univ. Bombay. 29: 39-48.

Ellis, M.M. 1937. Detection and Management of stream pollution. V. S. Bur. Fish. 48: 368437.

Elornata, P.V. 1982. Periphyton growth and diatom community structure in a cooling water pond. Hydrobiologia. 96 (3): 253-265. 
Eskinazi-Leea, E., Da Costa Alves, M.A. and De Paiva Rocha, I. 1980. Periphyton and its relationship with Muglidae culture. Simposio Brazilario De Aquacultura, Academia Brasileria de Cincias, Rio de Jeneiro, Brazil. pp. 109-119.

Ganapati, S.V. 1941. Seasonal changes in the physical and chemical conditions of garden pond containing abundant aquatic vegetation. J. Madras Univ. 13: 55-67.

Haque, M.M. 1996. Effects of periphyton on pond fish culture. M. S. Thesis. Department of Fisheries Biology and Limnology, Bangladesh Agricultural University, Mymensingh, Bangladesh. $86 \mathrm{p}$.

Islam, A.K.M.N. and Saha, S.K. 1975. Limnological studies of the Ramna Lake at Dhaka. Dhaka Univ. Stud. (B) 23: 39-48.

Jhingran, V.G. 1975. Aquaculture lecture, summer Int. Intensive Freshwater fish culture, Cuttack, Organized by Centr. Inland Fish. Res. Inst. Barrackpore (ICAR), $12 \mathrm{p}$.

Kawser, R. 1998. Effects of periphyton on production of major carps. M.S. Thesis. Department of Fisheries Management, Bangladesh Agricultural University, Mymensingh, Bangladesh. $83 \mathrm{p}$.

Khondker, M. and Rahim, S. 1993. Investigation on the water quality of Dhanmondi Lake, Bangladesh. Periphytic and planktonic algae as indicators. Bangladesh J. Bot. 22 (1): 4953.

Lagler, K.F. 1972. Freshwater Fishery Biology. 2nd ed. WMC Brown Comany Publishers, Dubuque, IOWA, 421 p.

Markosova, R. 1980. Effects of submerged substrates quality on the periphytic macro fauna in ponds. Vestn, Cesh. Spol. Zool. 44 (1): 46-52.

McCombie, A.M. 1953. Factors influencing the phytoplankton. J. Fish. Res. Bd. Canada, 10: 253-282.

Nahar, S. 1997. Effects of periphyton grown on different substrates on fish production. M.S. Thesis. Department of Fisheries Management, Bangladesh Agricultural University, Mymensingh, Bangladesh. 88 p.

Needham, J.G. and Needham, P.R. 1962. A guide to the study of Freshwater Biology. $5^{\text {th }} \mathrm{ed}$. Holden-day, Inc. Sanfrancisco. 108p.

Neverauskas, V.P. 1988. Accumulation of periphyton on artficial substrata near sewage sludge outfalls at Gunetg and Port Adelaide, South Australia. Trans. Royal Soc. South Australia. 122 (4): 175-177.

Odum, E.P. 1971. Fundamentals of Ecology. $3^{\text {rd }}$ edition. W. B. Saunders Company, Philadelphia, 574p.

Penak, R.W. 1953. Fresh water Invertebrates of the United States. The Ronald Press Company, New York. 769 p.
Presscott, G.W. 1962. Algae of the Western Great Lakes Area. Win. C. Brown Co. Dubuque, IOWA. $946 \mathrm{p}$.

Rahman, M.S. 1992. Water Quality Management in Aquaculture, BRAC Prokashana, 66, Mohakhali, Dhaka-1212, Bangladesh. 84 p.

Rahman, M.S. 1998. Formula for periphyton estimation. M.S. Thesis. Department of Fisheries Management, Bangladesh Agricultural University, Mymensingh. p. 25.

Rahman, M.S., Chowdhury, M.Y., Aminul Haque, A.K.M. and Haq, M.S. 1982. Limnological Studies of four ponds. Bangladesh J. Fish. 25(1-2): 25-35

Rashid, M.M. 1999. Effects of periphyton on monoculture of Labeo gonius. M. S. Thesis. Department of Fisheries Management, Bangladesh Agricultural University, Mymensingh, Bangladesh. 78 p.

Reid, G.K. and Wood, R. D. 1976. Ecology of Inland Waters and Estuaries. 2nd ed. Van. Nostrand Company, New York. 485 p.

Ruttner, F. 1953. Fundamentals of Limnology. University Toronto Press. Toronto. 243 p.

Smith, G.M. 1950. The Freshwater Algae of the United States. 2nd ed. McGraw Hill Book Company, New York. 719 p.

Sukane-Boonpirote. 1990. Species composition and quantitative study on periphyton in Nongttan, Hangwat Sakon Nakhon, Bangkok. $86 \mathrm{p}$.

Swingle, H.S. 1967. Standardization of chemical analyses for water and pond muds. FAO Fish. Rep., 4 (44): 397-421.

Tasneem, S.L. 1998. Effects of periphyton on monoculture of Labeo rohita. M.S. Thesis. Department of Fisheries Management, Bangladesh Agricultural University, Mymensingh, Bangladesh. 78 p.

Ward, H.B. and Whipple, G.C. 1959. Freshwater Biology. 2nd ed. John Wiley and Sons. Inc. USA. $1248 \mathrm{p}$.

Wargasamita, S. 1991. The use of periphytic algae and water quality index in the assessment of water quality. pp. 155-160. In: Bloom, H., J. J. Dodson, S. S. Tjitrosomo, R. C. Umaly, S. Sukimin (eds). Proceedings of the Symposium on Inland Aquatic Environmental Stress Monitoring, Bogor, Indonesia.

Welch, P.S. 1948. Limnological Methods. MoGraw-Hill Book Company, New York, 381 p.

Wilham, J., Cooper, J. and Namminga, H. 1978. Species composition, diversity of biomass and chlorophyll of periphyton in Greasy Creek, Red rock and the Arkansas river, OkalaHoma. Hydrobiologia. 57 (1): 17-23. 